Lignite and the Midway-Wilcox Stratigraphic Boundary, Alabama and Mississippi

\title{
By
}

C. R. Melssner, Jr. and S. E. Heermann

1982

Open-file Report 82-673

This report is preliminary and has not been reviewed for confornity with U.S. Geological Survey editorial standards and stratigraphic nomenclature. 
Introduction

The boundary between the Midway Group of Paleocene age and the overlying Wilcox Group of Paleocene - Lower Eocene age needs clarification in the border area along east-central Mississippi and west-central Alabama. A 1 ignite bed described in the Oak Hill Member of the Naheola Formation, upper Midway Group, in Alabama (Dantels, 1973) appears to be the same bed as that described in the Fearn Springs Member of the Nanafalia Formation, lower Wilcox Group, just across the border in Mississipp1 (Foster, 1940). If the lignite bed actually is continuous from Alabama into Mississippi, then it is impossible for tt to cross a major stratigraphic boundary such as that between the Midway and Wilcox Groups, especially since this boundary has been described as a major unconformity (Hughes, 1958). The U.S. Geological Survey Lexicon of Geologic Names of the United States from 1936-1960 (Reroher and others, 1966) cites eight authors, none of whom completely agree on the definition of the Fearn Springs Member and its stratigraphic position. MacNe11 (1946) gives the option of three different positions for the Midway-Wilcox boundary, one at the base of the Naheola Formation (upper Midway), one at the base of the Coal Bluff member of the Naheola, and one at the base of the Fearn Springs Member of the Nanafalia Formation (lower Wilcox) (fig. 1). In later work MacNe1l (1951) traced Fearn Springs into Alabama where 1t merged with the upper part of beds assigned to the Naheola (Coal Bluff member). He then considered the upper beds equivalent to the Fearn Springs and assigned them to the basal Nanafalia (lower Wilcox), and the lower beds (now called the Coal Bluff Marl Member which overlies the Oak Hill Member) were assigned to the Naheola (upper Midway). Recent paleontological work with micro and macro fossils in eastern Alabama by Norman 0. Frederiksen, Thomas G. Gibson, and others, of the U.S. Geological Survey, suggested that the Fearn Springs belongs in the upper part of the Midway Group (oral communications, 1982), but this has not been confirmed in western Alabama or :1ississippi.

None of the above cited information explains the apparent continuity of the Oak Hill lignite of Alabama into the Fearn Springs lignite of Mississippi and for this reason the authors of the present study conducted surface investigations in the region in an attempt to confirm the apparent continuity of the lignite bed and establish its relationship with the Midway-Wilcox formational boundary. These investigation are summarized below.

Surface Reconnaissance

During the period, January $12-23,1982$, the lignite bed described in the Fearn Springs Member of the Nanafalia Fornation (lower Vilcox) was traced from southern Kemper County, Mississippi, across the northeastern corner of Lauderdale County, Mississippi, into Sumter County, Alabama, a distance of about 20 miles (plate 1). The topography is gently rolling on poorly consolidated sandstone, siltstone and claystone and although exposures are few and far between, about twenty outcrops were visited. These include measured sections or isolated outcrops cited in the literature and those found on the recent reconnaissance. All of these exposures do not contain lignite, but at some places lignitic sediments and/or underclays occur at the same stratigraphic horizon indicating continuity of the horizon of the lignite bed. Elevations of the lignite outcrops were determined by altimeter. These 


\begin{tabular}{|c|c|c|c|}
\hline $\begin{array}{l}\infty \\
\stackrel{0}{\infty} \\
\frac{0}{0} \\
\infty\end{array}$ & $\frac{0}{3}$ & $\begin{array}{c}\text { East-Central } \\
\text { Mississippi }\end{array}$ & $\begin{array}{l}\text { Western } \\
\text { Alabuma }\end{array}$ \\
\hline $\begin{array}{l}0 \\
\mathbf{1} \\
0 \\
0\end{array}$ & $\begin{array}{ll}1 & x \\
0 & 0 \\
3 & 0 \\
0 & \vdots\end{array}$ & $\begin{array}{l}\text { Nanafalia Fm. } \\
\text { Fearn Springs Mbr. }\end{array}$ & $\begin{array}{l}\text { Nanafalia Fm. } \\
\text { Grampian Hills Mbr. } \\
\text {-Ostrea Thirsae beds } \\
\text { Gravel Creek Mbr. }\end{array}$ \\
\hline$\frac{1}{\infty}$ & 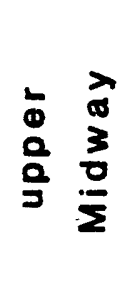 & $\begin{array}{l}\text { Naheola Fm. } \\
\text { Porters Creek Clay }\end{array}$ & $\begin{array}{c}\text { Naheola Fm. } \\
\text { Coal Bluff Marl Mbr. } \\
\text { Oak Hill Mbr. } \\
\text { Porters Creek Clay }\end{array}$ \\
\hline
\end{tabular}

Figure 1.--stratigraphic nomenclature of formations of the upper Midway and lower Wilcox Groups in east-central Mississippi and western Alabama. 
surface elevations were supplement by available drill-hole data obtained from the Kemper County, Mississippi, report (Hughes, 1958), the Lauderdale County, Mississippi, report (Foster, 1940), and lignite investigations in Sumter County, Alabama (Daniels, 1973). In all, elevation data were obtained for 40 points (plate 1 ).

\section{Structure Contour Map}

Structure contour lines at 10-foot intervals were drawn on top of the lignite bed (plate 1). These contours show a regional southwest dip averaging about 26 feet per mile, or about $1 / 4$ degree. This dip is similar to that reported in the literature by earlier workers. A small structural dome with over 40 feet of closure was contoured in Sumter County south of York, Ala. This dome is up to six miles long and $21 / 2$ miles wide. Surface evidence indicates a northeast reversal of dip up to 4 degrees along a cut on the St. Louis San Francisco Railroad about 4 miles south of York, Ala. Mapping along a creek a mile or so west of this cut also indicates northeast dip. The lignite bed at this railroad cut is part of the Oak Hill Member of the Naheola Formation (upper Miuway Group - Daniels, 1973).

\section{Isopach Map}

An isopach map of the Oak H1l1 - Fearn Springs(?) lignite bed was drawn from the thicknesses recorded in the same outcrop and drill hole data used in constructing the structure contour map (plate 2). The isopach map indicates a nearly continous bed from Sumter County, Ala., to Lauderdale County, Miss. Apparently, small parts of the bed in northeastern Lauderdale County may thin to zero or grade into lignitic and carbonaceous clay and silt. The thickest part of the bed is in Sumter County, Ala., south of York where it is up to nine feet thick in elongate pods. The bed trends northwestward into Laudertale County, Miss., where its thickness is up to 5.5 feet. The northeastern houndary of the bed is where it pinches out, or changes into lignitic and carbonaceous clay and silt, or where it crops out at the surface at its up-dip end. The down-dip boundary of the bed as contoured on the isopach map is simply limited to the available shallow well data. Actually, it is reasonable to assume the bed extends well down-dip into the subsurface to the southwest.

\section{Geologic Cross section}

A geologic cross section was constructed using published drill hole data of eight shallow holes extending along a line from Sumter County, Ala. into Kemper County, Miss. (plate 3). One of these holes is about 95 feet deep, whereas the remainder do not exceed 45 feet in depth. A single bed of lignite was penetrated in each hole shich is interpreted by the authors to be the same bed. This means, from southeast to northwest, the bed continues from the Oak Hill Member of the Naheola Formation (upper Midway Group) into what has been included in the Fearn Springs Member of the Nanafalia Fornation (lower Wilcox Group). In the construction of the cross section at a manageable size, the difference between the vertical and horizontal scale resulted in a vertical exaggeration of approximately 200 times normal. This exaggerated the dip between drill holes, which if drawn to the same vertical and horizontal scale, would show a very gentle dip between sections. None of the drill holes are deep enough to adequately reveal the stratigraphic 
relationship of the overlying sedimentary formations with the underlying formations. One hole, THR 56, does show the contact of Fearn Springs with Naheola. This contact, if accurate, shows the position of the lignite bed near the base of the Fearn Springs. None of the other holes show this contact, which also is supposedly the contact between the Wilcox Group and underlying Midway Group, so that the continuity and exact position of the Midway-Wilcox group contact cannot be ascertained. This is true in the area of other drill holes which are too shallow or widely spaced to satisfactorily trace the Midway-Wilcox contact or to deternine the relationship of this contact with the Oak Hill and the Fearn Springs Members. The continuity of the lignite bed indicates that the two members are equivalent, because the bed seeningly extends from one member into the other. However, the determination of the Midway-Wilcox boundary requires stratigraphic drilling of sufficient depth in the border area between Alabama and Mississippi to examine lower Wilcox-upper Midway sediments as a basis for defining and correlating formations in this area.

\section{Proposed Drilling Program}

It is proposed that a cooperative drilling program involving agencies from the states of Alabama and Missississippi and the J.S. Geological Survey be initiated in the area along the Oak Hill - Fearn Springs lignite bed trending from the south of York in Sumter County, Ala. through the northeastern corner of Lauderdale County, Miss. (plates 1 and 2). The drilling plan would be to locate a series of southeast-northwest trending test holes spudding into the lower part of the Wilcox Group, and drilling through the Naheola Formation of the upper part of the Midway Group and into the Porters Creek Clay of the Midway Group, which underlies the Naheola and is easily identified in the subsurface. It is estimated that the maximum depth of these holes would be 200 feet. The purpose of this drilling would be twofold. One, to determine the continulty of the Oak Hill - Fearn Springs(?) lignite bed between Alabama and Mississippi, and two, to clarify the boundary between the Wilcox and Midway Groups. The holes should be logged in all cases, and selectively cored for samples for petrographic and chemical analyses, and for sedimentological and palentological determinations. Such a drilling program would have both scientific and economic impact and more detailed plans could be mutually worked out if the proposal is accepted by the parties concerned. 


\section{References}

Daniels, T.W., Jr., 1973, A strippable Lignite Bed In South Alabama:

Geological Survey of Alabama Bulletin 101, 101 p.

Foster, V.M., 1940, Lauderdale County mineral Resources: Mississipp1 Geological Survey Bulletin 41, 246 p.

Hughes, R.J., Jr. 1958, Kemper County Geology: Mississippi State Geological Survey Bulletin 84, 274 p.

Keroher, G.C., and others, 1966, Lexicon of Geologic Names of the United States for 1936-1960: U.S. Geological Survey Bulletin 1200, part 1, p. 1332-1334.

MacNeil, F.S., 1946, Summary of the Midway and Wilcox Stratigraphy of Alabama and Mississippi: U.S. Geological Survey Strategic Minerals Investigations, Preliminary Report 3-195, 29 p.

Macie11, F.S., 1951, Fearn Springs Member of Wilcox Formation in Mississippi: Bulletin of the American Association of Petroleum Geologists, Vol. 35, no. 5, p. 1062-1070.

Williamson, D.R., 1976, An Investigation of the Tertlary Lignites of Mississippi: Mississippi Geological, Economic, and Topographical Survey Information Series MGS-74-1, 146 p. 